\title{
Doğum Sonrası Depresyonun Tanı ve Tedavisi: Bir Gözden Geçirme
}

\section{Ali Erdoğan*, Çiçek Hocaoğlu}

DOI: $10.17944 / m k u t f d .584854$

Ali Erdoğan: Öğr. Grv. Dr, Akdeniz Üniversitesi Tıp Fakültesi Psikiyatri Anabilim Dalı, Antalya Email: erdoganali006@hotmail.com ORCID iD: https://orcid.org/0000-0003-0329-6778

Çiçek Hocaoğlu: Prof. Dr., Recep Tayyip Erdoğan Üniversitesi Tıp Fakültesi, Psikiyatri Anabilim Dalı, Rize

Email: cicek.hocaoglu@erdogan.edu.tr

ORCID iD: https://orcid.org/0000-0001-6613-4317

Bildirimler/Acknowledgement

* Sorumlu Yazar/Corresponding Author

Çıkar Çatıșması/Conflict of Interest Yazarlar bu makale ile ilgili herhangi bir çıkar çatıșması bildirmemișlerdir.

The authors declare that they have no conflict of interests regarding content of this article.

Maddi Destek/Financial Support

Yazarlar bu makale ile ilgili herhangi bir finansal destek bildirmemisterdir.

The Authors report no financial support regarding content of this article.

Etik Beyan/Ethical Declaration

Yazarlar, çalıșma için etik kurul iznine ihtiyac bulunmadığını, çalıșmanın yürütülmesi esnasında Helsinki Beyannamesi 2013, ICJM tavsiyeleri ile COPE'un Editör ve Yazarlar için Uluslararası Standartlarının yanısıra ilgili diğer biyoetik kılavuzların dikkate alındığını beyan etmișlerdir.

Geliș/Received: 01.07.2019

Kabul/Accepted: 25.09.2019

e-ISSN: 2149-3103

Web: http://dergipark.org.tr/mkutfd
Öz

Doğum Sonrası Depresyonun Tanı ve Tedavisi: Bir Gözden Geçirme

Gebelik dönemi kadın yașamında fizyolojik, ruhsal ve sosyal değișimlerin yașandığı bir dönemdir. Gebelik dönemi ve sonrasındaki bu değişimler çeșitli ruhsal hastalıklara sebep olabilmektedir. Bu hastalıklardan doğum sonrası depresyon perinatal dönemde sık görülmektedir. Doğum sonrası depresyon anne ve bebek için önemli bir morbidite ve mortalite sebebidir. Peripartum bașlangıçlı bir major depresif epizod hamilelikte veya doğum sonrası 4 haftaya kadar ortaya çıktığında doğum sonrası depresyon olarak tanımlanmaktadır. Sıklığı son derece yüksektir. Etiyolojisinde biyolojik, psikolojik ve sosyokültürel faktörlerin etkili olduğu bildirilmektedir. Çökkünlük, anhedoni, suçluluk düșünceleri, sinirlilik, konsantrasyon bozukluğu, psikomotor ajitasyon, psikomotor retardasyon, uyku düzensizliği, iștah ve kilo değişiklikleri gibi major depresyon semptomları ile prezante olur. Tedavisinde ise birçok farklı seçenek bulunmaktadır. Bu seçeneklerin çoğu major depresyon tedavisinden uyarlanmıștır. Tedavide serotonin geri alım inhibitörleri (SSRI), serotonin noradrenalin geri alım inhibitörleri (SNRI), trisiklik antidepresanlar, östradiol, progesteron, psikoterapiler, elektronvulsiv terapi ve brexanolone kullanılabilmektedir. Brexanolone doğum sonrası depresyon tedavisinde umut vaat eden yeni bir ilaçtır. Doğum sonrası depresyona özel endikasyon almıș tek tedavidir. Bu derleme çalıșması, güncel veriler ışığında doğum sonrası depresyonun etiyoloji, tanı ve tedavisindeki yeni gelișmeleri incelemeyi amaçlamaktadır.

Anahtar Kelimeler: Doğum sonrası depresyon, depresyon, tedavi, brexanolone

\section{Abstract}

Diagnosis and Treatment of Postpartum Depression: A Review

Pregnancy is a period in which physiological, psychological and social changes are experienced in female life. These changes can cause various mental illnesses during and after pregnancy. Postpartum depression is commonly seen in the perinatal period. Postpartum depression is an important cause of morbidity and mortality for mother and baby. A major depressive episode with peripartum onset is defined as postpartum depression when it occurs during pregnancy or up to 4 weeks of postpartum. The frequency of the disease is extremely high. Biological, psychological and sociocultural factors have been reported to be effective in the etiology. It presents with major depression symptoms such as depression, anhedonia, thoughts of guilt, irritability, concentration disorder, psychomotor agitation, psychomotor retardation, sleep disorder, appetite and weight changes. There are many different options in the treatment. Most of these options have been adapted from the treatment of major depression. Serotonin reuptake inhibitors (SSRI), serotonin noradrenaline reuptake inhibitors (SNRIS), tricyclic antidepressants, estradiol, progesterone, psychotherapies, electroconvulsive therapy and brexanolone may be used in the treatment. Brexanolone is a promising new drug in the treatment of postpartum depression. It is the only treatment in postpartum depression that has received special indication. This review aims to investigate the recent developments in the etiology, diagnosis and treatment of postpartum depression in the light of current data.

Keywords: Postpartum depression, depression, treatment, brexanolone

\section{GİRIŞ}

Gebelik dönemi kadın yaşamında fizyolojik, ruhsal ve sosyal değişimlerin yaşandığı ve bu değişimlere uyumu gerektiren önemli bir süreçtir. Gebelik esnasında, doğumda ve doğum sonrasında oluşan değişiklikler kadınlarda çeşitli ruhsal hastalıklara sebep olabilmektedir (1). Doğum sonrası depresyon (DSD) perinatal dönemde sık görülen, anne ve bebek için önemli bir morbidite ve mortalite sebebi olan bir psikiyatrik hastalıktır (2). Doğum sonrası depresyon son derece sık görülmesine rağmen klinik pratikte gözden kaçabilmektedir. Diğer duygudurum bozukluklarından farklı klinik görünüm ve etiyolojiye sahiptir (3). Doğum sonrası depresyonda yüksek intihar oranları görülmektedir (4). Anne, bebek ve diğer aile bireylerinin yaşam kalitesini olumsuz etkilemektedir (3). Bu çalışmamızda doğum sonrası depresyonunun klinik görünümü, etiyolojisi, tanı ve tedavi yaklaşımlarına ilişkin güncel literatür bilgileri ele alınacaktır. 


\section{Tanım}

Doğum sonrası depresyon sık görülen bir hastalık olmasına rağmen tanımlamalarda farklılıklar bulunmaktadır. DSM-5'te peripartum başlangıçlı bir major depresif epizod hamilelikte veya doğum sonrası 4 haftaya kadar ortaya çıtığında doğum sonrası depresyon olarak tanımlanmaktadır (5). Dünya Sağlık Örgütü (WHO) ise doğum sonrası 1 ylla kadar olan dönemi doğum sonrası depresyon olarak tanımlamıştır (3). Diğer yaygın tanı ve sınıflandırma sistemi olan ICD-10 ise, doğumdan sonraki altı hafta içinde başlayan mental bozuklukları puerperiumla ilişkilendirmektedir (6).

\section{Epidemiyolojisi}

Doğum sonrası depresyon sıklı̆̆ı son derece yüksektir. Dünya çapında doğum sonrası depresyon hamilelik sırasında veya sonrasındaki kadınların \%20 sini etkilemektedir. ABD'de doğum sonrası depresyon yaygınlığı \%11,5 olarak bildirilmiştir (2). ABD'de her yll 750000 anneyi etkilediği tahmin edilmektedir (7). Doğum sonrası ilk 3 ay annelerde depresyon oranları \%19.2'ye kadar varan oranlarda raporlanmıştır (8). Ülkemizde yapılan çalışmalara bakacak olursak doğum sonrası depresyon oranı bir çalışmada \%28 olarak saptanmıştır (9). Başka bir çalışmada ülkemizde doğum sonrası depresyon oranı \%23 olarak bildirilmiştir (10). Ülkemizde doğum sonrası birinci hafta ile 18. ay arasında yapılan çalışmalarda doğum sonrası depresyon yaygınlığı $\% 12,5$ ile \%42,7 arasında değişmektedir $(11,12)$.

Literatürde yaygınlık belirlenirken farklı zaman aralıkları, farklı monitörizasyon yöntemleri ve tanı ölçütleri kullanılmakta, bu yüzden doğum sonrası depresyon yaygınlığı farklı çalışmalarda farklılıklar göstermektedir (13).

\section{Etiyoloji (biyolojik, psikososyal, psikolojik)}

DSD'nin etiyolojisinde biyolojik, psikolojik ve sosyokültürel faktörlerin etkili olduğu bildirilmektedir $(14,15)$. Doğum sonrası depresyon etiyolojisinde yer alan psikososyal etkenler kültürler arasında farklılıklar göstermektedir. Doğum sonrası dönem birçok kültürde önem arz etmekte, bu dönemde anne ve bebeğin sağlığı için geleneksel uygulamalar yapılabilmektedir. Bir kısmı yararlı olabilmekle birlikte bir takım geleneksel uygulamalar doğum sonrası depresyona sebep olabilmektedir (16). Sosyal destek eksikliği doğum sonrası depresyon riskini artıran önemli etkenlerden biri olarak bilinmektedir. Geçirilmiş depresyon öyküsü, genç yaş, çocuk bakımına ilişkin yaşanan sorunlar, stresli yaşam olayları, annelik hüznü, olumsuz evlilik ilişkileri, evlilik ilişkisinin zayıf olması, beden imgesinde değişiklikler, düşük sosyoekonomik durum ve gebeliğin istenmeme durumu doğum sonrası depresyona yatkınlığı arttırabilmektedir (9). Gebelik esnasında oluşan fizyolojik değişiklikler de gebelerde depresyon sıklığını arttırabilmektedir. Bu değișikliklerden kilo artışı, bulantı, solunum kapasitesi değişiklikleri gibi durumların gebede memnuniyetsizlik yaratmasına bağlı olarak hem gebelik süresince hem de postpartum dönemde kadınlarda depresif belirtiler artabilmektedir (17). Doğum ve sonrası dönemde meydana gelen hormonal değişiklikler de doğum sonrası depresyon etiyolojisinde önemli rol oynamaktadır. Gebelik sırasında ve doğum sonrası dönemde steroid ve peptid hormonların seviyeleri etiyolojiye katkıda bulunabilecek düzeyde çarpıcı şekilde dalgalanır. Bu hormon seviyelerindeki dalgalanmalar östradiol, kortikosteron, kortizol, progesteron, $\mathrm{CRH}$, oksitosin gibi hormonları içermekte olup farklı gebelik dönemlerinde ve farklı profillerde olmaktadır. $\mathrm{Bu}$ hormonların seviyeleri ciddi miktarlarda yükselmekte ve plasenta atılımı ile düşme eğilimi göstermektedir (18). Bifazik östradiol ile yapılan plasebo kontrollü bir çalışmada azalmış östradiol düzeyleri ile Hamilton depresyon skorlarında artma arasında pozitif korelasyon tespit edilmiş ve bunun kadınlarda neokorteksteki artmış serotonin taşıyıcı düzeyleri ile korele olduğu bildirilmiştir. Bu durumda muhtemelen serotonin azalmasına neden olmaktadır (19). Yine bir çalışmada doğumdan önceki androjen ve östrojen düzeyleri doğum sonrası orta derecede depresyon ile ilişkili bulunmuştur. Bu bulgular maternal ve fetal steroidejenezdeki değişikliklerin doğum sonrası depresyon etiyolojisinde etkili olduğunu düşündürmektedir (20). Epigenetik modifikasyonların incelenmesi ile doğum sonrası depresyonda DNA metilasyon paternlerinde değişiklikler tespit edilmiştir (21). Nörobiyolojik çalışmalarda da ruh hali ne olursa olsun postpartum dönemde prefrontal korkteks ve hipokampusta nöroplastik değişiklikler olmaktadır. Örneğin total beyin volümü azalmakta ve doğum sonrası 6 ayda tekrar normal seviyesine gelmektedir. Bu da bazı kadınların doğum sonrası depresyona açık olmalarına katkıda bulunabilmektedir (22).

\section{Risk Faktörleri}

Gebelik depresyonuna zemin hazırlayan çeşitli risk faktörleri bulunmaktadır. Gebenin sosyal destek sistemleri ile gebelik depresyonu arasında sıkı bir ilişki bulunmaktadır. Gebelikte eş desteğinin olmamasının ya da sosyal destek zayıflığının depresyon gelişimine etkisi olduğunu saptamıştır (23). Bir çalışmada özsaygısı düşük olan, anksiyete yaşayan, sosyal desteği az ya da hiç olmayan, sürekli olumsuz yönde düşünme eğilimi olan, yaşamında büyük bir travma yaşamış, geçmişinde şiddet gören kadınlarda gebelik depresyonu riski yüksek saptanmıştır. Aynı çalışmada ilk ebeveyn olma stresi ile gebelik depresyonu arasında da an- 
lamlı bir ilişki bulunmuştur (24). İstenmeyen gebelik ve erken yaşta gebe kalma ile depresyon arasında pozitif yönde anlamlı bir ilişki bildirilmiştir. Gebenin geçmişteki gebelik öyküsü ve gebelikte yaşadığı duygusal ve fiziksel sorunlar gebelik depresyonu için risk faktörleridir. Gebenin geçmişinde depresyon öyküsünün olması, gebeliğine yönelik olumsuz duygular, geçmişinde psikiyatrik hastalıkların varlığı gibi nedenler gebelik depresyonunu etkileyen diğer risk faktörleridir. Ruhsal ve fiziksel travma, stres, kronik hastalıklar, enfeksiyonlar, oral kontraseptif kullanma gebelik sonrası depresyon için çevresel risk faktörleridir. Çevresel faktörler genetik yatkınlıkla birlikte depresyon riskini arttırmaktadır. Genetik faktörlerle ilgili veriler net olmamakla birlikte doğum sonrası depresyonun yaklaşık \%50'sinin genetik faktörlerle ilişkisinin olduğu ileri sürülmektedir (25).

\section{Tanı ve klinik görüinüm}

Doğum sonrası depresyon oranları oldukça yüksek olmakla birlikte doğum sonrası depresyon sıklıkla atlanan ve tedavisiz kalan bir hastalıktır. Gebelerdeki depresif belirti ve bulguların; gebeliğin fizyolojik değişiklikleri ve yakınmalarıyla benzer özellikte olması ve subsendromal özellik gösterebilmesi nedeniyle gebelik depresyonuna tanı koymak bazen güç olabilir (23). Uzamış ve ciddi semptomları olan kadınlara tanı konmakta diğerleri atlanabilmektedir. Doğum sonrası depresyon semptomları heterojendir. Çökkünlük, anhedoni, suçluluk düşünceleri, sinirlilik, konsantrasyon bozukluğu, psikomotor ajitasyon, psikomotor retardasyon, uyku düzensizliği, iştah ve kilo değişiklikleri gibi major depresyon semptomları ile prezante olur (26). Hastalık şiddeti fazla olan hastalarda intihar düşünceleri, intihar girişimleri, bebek bakımını aksatma ve hatta bebeğe zarar verme davranışı olabilir. Doğum sonrası depresyonda intihar düşüncesi hastaların yaklaşık \%5-14'ünde görülür. Doğum sonrası ilk 1 yılda anne ölüm nedenleri arasında önemli bir yer tutmaktadır (4). Doğum sonrası depresyonda eşlik eden psikiyatrik hastalıklar sık görülmektedir ve bu semptom çeşitliliğinin artmasına, tedavi direncine ve intihar riskinin artmasına sebep olmaktadır (27). Gebelik dönemi ve doğum sonrası dönemde iyi bir ruhsal muayene ve güvenilir tarama yöntemleri kullanılarak doğum sonrası depresyon saptanabilir. Doğum sonrası depresyonu taramak için Doğum Sonrası Depresyon Tarama Ölçeği, Beck Depresyon Ölçeği, Hamilton Depresyon Ölçeği (HAM-D), Edinburgh Doğum Sonrası Depresyon Ölçeği ve Durumluluk Süreklilik Kaygı Envanteri kullanılabilir. Bu ölçekler, doğum sonrası dönemdeki kadınlarda depresyon riskini belirlemeye yönelik tarama amaçlı hazırlanmış olup, depresyon tanısı koymaya yönelik değildir. Bu ölçeklerden alınan puanlar ile beraber hastanın genel durumu, öyküsü ve ruhsal muayenesi ile ayırıcı tanıya gidilebilir (28). Tanı koymada DSM-5 ve ICD-10 gibi sinıflandırma sistemleri kullanıl- makta ancak psikiyatrik tanı sistemlerinde gebelik dönemi ve postpartum dönemde görülen psikiyatrik bozukluklar ayrı bir klinik tanı olarak tanımlanmamaktadır. Ayrıca DSM-IV-TR ile DSM-5 sinıflandırma sistemleri arasında depresif bozukluk belirteçlerinde büyük farklılık da bulunmamaktadır. Ancak, DSM-IV-TR sinıflandırma sisteminde postpartum başlangıçlı depresyon olarak ele alınan klinik durumun, \%50 oranda gebelik dönemi içinde başlangıç gösterdiğine değinilerek, bu belirteç daha önceki "postpartum başlangıçlı" tanımlaması yerine DSM-5 sınıflandırma sisteminde "peripartum başlangıçlı" olarak tanımlanmıştır. DSM-5 Depresyon bozuklukları başlığı içerisinde; yıkıcı duygudurumu düzenleyememe bozukluğu, yeğin (majör) depresyon bozukluğu, süregiden depresyon bozukluğu (distimi), aybaşı öncesi (premenstrüel) disfori bozukluğu, maddenin/ilacın yol açtığı depresyon bozukluğu, başka bir sağlık durumuna bağlı depresyon bozukluğu, tanımlanmış diğer bir depresyon bozukluğu ve tanımlanmamış depresyon bozukluğu bölümleri yer almaktadır. DSM-5’te peripartum başlangıçlı bir major depresif epizod hamilelikte veya doğum sonrası 4 haftaya kadar ortaya çıktığında doğum sonrası depresyon olarak tanımlanmaktadır (5). Diğer yaygın tanı ve sınıflandırma sistemi olan ICD-10 ise, doğumdan sonraki altı hafta içinde başlayan depresif bozuklukları doğum sonrası depresyon olarak tanımlamakta$\operatorname{dir}(6)$.

\section{Tedavi yaklaşımları}

Doğum sonrası depresyon tedavisi ile ilgili çok geniş bir literatür bulunmaktadır. Birçok tedavi major depresyon tedavisinden uyarlanmış olup doğum sonrası depresyon için özel olarak onay almış tedavi sayısı kısıtlıdır. Tedavide serotonin geri alım inhibitörleri (SSRI), serotonin noradrenalin geri alım inhibitörleri (SNRI), trisiklik antidepresanlar, östradiol, progesteron, psikoterapiler, elektronvulsiv terapi ve brexalonone kullanılabilmektedir (29-35). Doğum sonrası depresyon tedavisinde hastanın çok küçük bir çocuğa bakım verdiği her zaman akılda tutulmalıdır. Çocuklar farmakolojik müdahalelerden etkilenebilmektedir. Bu yüzden doğum sonrası depresyon hastalarında tedaviye karşı isteksizlik belirgindir ve sadece \%18'i etkili bir tedavi almaktadır (36).

\section{Psikoterapiler}

Farklı psikoterapi yöntemleri doğum sonrası depresyon tedavisinde kullanılmıştır. Birleşik Krallık'ta doğum sonrası dönemde dinleme ziyareti adında bir yöntem geliştirilmiştir. Dinleme ziyaretinde doğum sonrası kadınlar evlerinde 46 seans arasında ziyaret edilmekte ve dinleme ziyaretleri yansıtıcı dinleme ve problem çözmeyi içermektedir. Özellikle Birleşik Krallık'ta perinatal dönemde kanıta 
dayalı etkili bir terapi yöntemi olarak kullanılmaktadır (29).

Kişilerarası psikoterapi depresyon tedavisinde etkin olarak kullanılan bir terapi yöntemidir ve postpartum depresyon tedavisi için de etkin bir biçimde kullanılabilmektedir (7).

Doğum sonrası depresyon tedavisinde kullanılan bir başka terapi yöntemi ise bilişsel davranışçı terapidir. Bilişsel davranışçı terapinin doğum sonrası depresyon tedavisinde etkili olduğunu bildiren çalışmalar bulunmakla birlikte diğer terapi yöntemlerinden daha etkili olmadığ bildirilmiştir (37).

\section{Serotonin geri alım inhibitörleri}

Hafif ve orta şiddetli doğum sonrası depresyon tedavisinde genellikle birinci sıra tedavi serotonin geri alım inhibitörleridir. Gebelik sırasında SSRI etkinliğini ölçen çok fazla literatür bulunmamaktadır. Her ne kadar farklı sonuçlar bulunsada SSRI'ların doğum sonrası depresyonda etkin oldukları kabul edilir (37). Essitalopram ve fluvoksamin için açık etiketli kanıtlar vardır ve randomize kontrollü çalışma bulunmamaktadır. Sitalopram için yeterli bilgi bulunmamaktadır. Genel olarak sertralin doğum sonrası depresyon tedavisinde hakkında en çok kanıt bulunan SSRI'dır. Sistematik bir gözden geçirmede SSRI'lar, nortriptilin ve psikoterapinin doğum sonrası depresyonun erken dönem tedavisinde etkili oldukları bildirilmiş ancak birbirine üstünlükleri ile ilgili kanıt bildirilmemiştir (38).

\section{Serotonin norepinefrin geri alım}

\section{inhibitörleri}

Doğum sonrası depresyon tedavisinde duloksetin, venlafaksin, milnasipran ve desvenlafaksin gibi SNRI grubu ilaçların etkili olduğuna dair randomize kontrollü açık kanıtlar bulunmamaktadır. Açık etiketli çalışmalarda venlafaksin ve desvenlafaksinin semptomları düzeltmede etkili olduğu vurgulanmıştır. Yine diğer antidepresanlardan bupropion, mirtazapin, trazadon ve nefazadone ile ilgili randomize kontrollü çalışma bulunmamaktadır. Sadece bupropion ve nefazadone kullanımını destekleyen açık etiketli çalışmalar bulunmaktadır $(36,39)$.

\section{Trisiklik antidepresanlar ve monoamin}

\section{oksidaz inhibitörleri}

Doğum sonrası depresyon tedavisinde Nortriptilin ile ilgili az sayıda veri bulunmakta olup, diğer trisiklik antidepresanlar ve MAO inhibitörleri ile ilgili yeterli veri bulunma- maktadır (32).

\section{Östradiol ve Progestin ile müdahale}

Östradiol ve Progestinin doğum sonrası depresyon tedavisinde etkisi konusunda yeni çalışmalar bulunmaktadır. Bir çalışmada şiddetli doğum sonrası depresyonu olan bir grup hastada $17 \beta$-östradiol ile plasebo içeren transdermal yamalar karşılaştırılmış, tedavinin ilk ayında östrojen alan grupta Edinburg Doğum Sonrası Depresyon ölçeği puanlarında belirgin azalma gözlenmiş ancak her iki grupta da tam semptom remisyonu sağlanamamıştır (40). Sentetik progesteronların bazı çalışmalarda doğum sonrası depresif semptomlarla ilişkisi olduğu bildirilmiştir. Sentetik progesteronlar doğuım sonrası depresyonu önlemek için kullanılmamalı ve doğum sonrası kadınlarda dikkatli kullanılmalı$\operatorname{dir}(33)$.

\section{Elektrokonvulsiv terapi ve diğer}

\section{nöromodulasyon yöntemleri}

Elektrokonvulziv terapi ağır ve dirençli doğum sonrası depresyon hastalarında etkili bir tedavi yöntemidir. Hamilelikte EKT kullanımı ile ilgili kılavuzlar yayınlanmıș olmasına rağmen, doğum sonrası depresyon tedavisinde EKT kullanımı ile ilgili randomize kontrollü çalışma bulunmamaktadır (34).

Transkranial magnetik stimülasyon ve transkranial doğru akım stimülasyonunun doğum sonrası depresyon tedavisindeki yeri ile ilgili çalışmalar deneme aşamasında olup elimizdeki veriler yetersizdir (41).

\section{Brexanolone}

Hipotalamik Hipofizer Adrenal Aks, perinatal hormonal dalgalanmalar ve $\gamma$-aminobutirik asit (GABA) sinyalizasyonu doğum sonrası depresyon patofizyolojisiyle ilișkilendirilmiştir (42). Bir çalışmada GABA disfonksiyonu oluşturulan farelerde doğum sonrası depresyona benzer semptomlar görülmüştür (43). Endojen bir progesteron metaboliti ve GABA tip A reseptörlerinin sinaptik ve ekstrasinaptik pozitif allosterik modülatörü olan allopregnanolonun plazma konsantrasyonları doğum sonrası önemli ölçüde azalmaktadır. Bu da bize GABA regülasyonu ve perinatal hormonal dalgalanma arasında bir ilişkiyi göstermektedir. Bu hipotezden yola çıkarak çözünür $\beta$-cyclodextrin tabanlı, allopregnanolon intravenöz formülasyonu-brexanolone enjeksiyon (SAGE 547 enjeksiyon) doğum sonrası depresyon için spesifik olarak onay alan ilk antidepresan olmuştur (44). Daha önce doğum sonrası depresyon tedavisi için spesifik olarak onay alan hiçbir molekül olmamıştır. Brexa- 
nolone doğum sonrası depresyon tedavisi için California Üniversitesi'nde Sage Therapeutics tarafından geliştirilen GABA-A reseptör pozitif allosterik modülatörü olan nöroaktif steroid yapısında küçük bir moleküldür. İlaç sentetik allopregnanolon ve sulfobutylether-beta-cyclodextrin karışımından oluşmaktadır. Cyclodextrin çözülmeyi sağlamak için eklenmiştir. Amerikan İlaç ve Gıda Dairesi (FDA) tarafından 19 Mart 2019 tarihinde ilk defa küresel onay almıştır. Aşırı sedasyon ve ani bilinç kaybı gibi ciddi yan etkiler sebebiyle brexanolone sadece bir risk değerlendirme ve azaltma stratejisi (REMS) altında sınırlı olarak uygulanabilmektedir. Brexalonon 2.5 gün infüzyon şeklinde uygulanmakta ve bu sürede hasta sürekli olarak nabız ve saturasyon yönünden monitörize edilmelidir. Hastaya gerektiğinde acil müdahale edilebilecek bir sağlık kuruluşunda tedavi uygulanmalıdır. Hastaların çocukları ile etkileşimleri sırasında mutlaka sağlık personeli hastalara eşlik etmelidir. Doğum sonrası depresyon tedavisinde etki mekanizması tam olarak anlaşılamamıştır ancak GABA-A reseptörleri pozitif allosterik modülasyonu ile ilgili olduğu düşünülmektedir. Brexanolone 30 ile $270 \mu \mathrm{g} / \mathrm{kg} / \mathrm{h}$ dozaj aralığında doz orantılı farmakokinetik etkiler gösterir. Geniş bir doku dağılımı gösterir $(\approx 3 \mathrm{~L} / \mathrm{kg})$. İlaç plazma proteinlerine \%99 oranında bağlanır ve plazma konsantrasyonundan bağımsız olarak yoğun şekilde bağlanmaktadır. Yarılanma ömrü yaklaşık 9 saattir ve total plazma klerensi $1 \mathrm{~L} / \mathrm{h} / \mathrm{kg}$ 'dır. Ketoredüksiyon, glukroniasyon ve sülfasyon gibi CYP dışı yolaklarla çoğu metabolize edilir. Her üç metabolitte farmakolojik olarak inaktiftir. $\% 47$ feçesle, $\% 42$ idrarla ve \%1’i değişmeden idrarla ilaç olarak atılır. Diğer ilaçların brexanolon üzerindeki etkilerini değerlendirmek için spesifik bir ilaç etkileşimi çalışması bulunmamakla birlikte fenitoinle birlikte kullanıldığında fenitoin farmakokinetiğinde bir değişiklik görülmemiştir (35). 12 sağlıklı kadında yapılan bir emzirme çalışmasına dayanarak, brexanolonun süte geçtiği söylenebilir ancak göreceli bebek dozu düşüktür. (maternal dozun 1-2\%) (45, 46). Yetişkinlerde brexanolon oral biyoyararlanım (\%5) çok düşüktür. Kadınların \%95'inden fazlasında, sütteki brexanolon konsantrasyonları, infüzyonun kesilmesinden 36 saat sonra (10 ng/ $\mathrm{mL}$ ) düşük seviyelerde ölçülmüştür. Brexanolonun farmakokinetiği, renal (şiddetli böbrek yetmezliği çalışması) veya hepatik bozukluklardan (orta ve şiddetli hepatik bozukluk çalışması) etkilenmemektedir. Son dönem böbrek yetmezliğindeki (GFR<15 mL/dk/1.73 m2) farmakokinetiği ile ilgili bilgi bulunmamaktadır. Şiddetli böbrek yetmezliğinde cyclodextrin gibi çözücü moleküllerin plazma konsantrasyonları artmaktadır. Bu nedenle, çözücü maddenin potansiyel birikimi nedeniyle, son dönem böbrek yetmezliği hastalarında brexanolone kullanımından kaçınılmalıdır (35).

18-45 yaş arası kadınlarda doğum sonrası depresyon tedavisinde 60 saat sürekli intravenöz infüzyonun etkinliği randomize, çift-kör, çok merkezli çalışmalar ile gösterilmiş- tir. 18 yaş altı kullanım ile ilgili yeterli veri bulunmamaktadır. Plasebo kontrollü iki çalışmada 6 aydan daha kısa süredir doğum sonrası depresyon tanısı almış olan kadınların HAM-D toplam puanı infüzyon öncesi, çalışmanın birinde 26 ve üzerinde (şiddetli DSD) ve diğer çalıșmada 20-25 arasında saptanmıştır (orta DSD). Çalışmalarda hastalara 60 saat süreyle plasebo ve brexanolone infüzyonu 60 veya 90 $\mu \mathrm{g} / \mathrm{kg} / \mathrm{h}$ olarak titre edilmiştir. Her iki çalışmada ve her iki dozda HAM-D toplam puanı plaseboya göre anlamlı derecede azalmıştır. İnfüzyonun bitirilmesinden $24,36,48,60$, 72 saat ve 7,30 gün sonra tüm zaman dilimlerinde HAM-D puanları plaseboya göre anlamlı derecede düşük saptanmıştır. Bu çalışmalarda hastaların ek başka antidepresan alıp almamasına bakılmaksızın brexanolone grubunda plaseboya göre HAM-D skorları anlamlı derecede azalmıştır. Montgomery-Åsberg Depresyon Değerlendirme Ölçeği (MADRS) toplam skoru da brexanolone alan grupta plaseboya göre $24,48,60,72$ saat ve 7,30 gün takip sonrası anlamlı derecede azalmıştır $(44,47)$.

Başka bir çalışmada 18-45 yaş arası Hamilton Depresyon Değerlendirme Ölçeği için (HAM-D) toplam puanı 20 ve üzerinde olan doğum sonrası depresyonu olan 4 kadın açık etiketli bir çalışmaya alınmıştır. Tüm katılımcılarda 60 saat brexanolone infüzyonu ile HAM-D toplam puanları remisyon değerlerinde olacak şekilde anlamlı derecede azalmıştır (48).

Klinik çalışmalarda brexanolone 60 saat intravenöz infüzyonda iyi tolere edilmektedir (44). Ancak çalışmalarda bazı yan etkiler bildirilmiştir. En sık görülen yan etkiler (insidans $\geq \% 5$ ve plasebonun 2 katından fazla) brexanolon 60 $\mu \mathrm{g} / \mathrm{kg} / \mathrm{h}$, brexanolone $90 \mu \mathrm{g} / \mathrm{kg} / \mathrm{h}$ ve plasebo gruplarında sedasyon/somnolans (sirasıyla \%21, \%13 ve \%6), ağız kuruluğu (sırasıyla \%11, \%3 ve \%1), bilinç kaybı (sırasıyla \%5, $\% 3, \% 0)$ ve flushingdir (\%5, \%2 ve \%0). Hastalar infüzyon sonrası 4 hafta takip edilmiştir. Plasebo kontrollü çalışmaların analizinde, brexanolone alıcıların \%2'si (plasebo grubunda \%1) herhangi bir yan etki nedeniyle tedaviye devam etmemişlerdir. Tedavi devamını engelleyen bilinç kaybı, vertigo, senkop gibi sedasyon ile ilgili yan etkiler ya da infüzyon yerinde ağrı gibi yan etkiler olmuştur. Yan etkiler, brexanolone alıcıların \%7'sinde ve plasebo alıcılarının \%3'ünde tedavi kesilmesi veya doz azaltma ile sonuçlanmıştır. İnfüzyon sırasında dozun kesilmesi veya azaltılması gereken brexanolone ile tedavi edilen hastaların \%5’i (plasebo ile \%0) yine sedasyon ve somnolans yaşamışlardır. Doz kesintisi sonrası bilinç kaybının geri dönmesi 15-60 dakika arasında olmaktadır. Tüm bu veriler ışığında seçilmiş vakalarda brexanolone tedavisi doğum sonrası depresyon tedavisi için yeni bir umut gibi gözükmektedir. Bu konuda daha çok ve geniş randomize kontrollü çalışmalara ihtiyaç vardır $(47,48)$. 


\section{SONUÇ}

Doğum sonrası depresyon anne ve bebek sağlığını son derece olumsuz etkileyen ve tanısı sık atlanan bir klinik sendromdur. Doğum sonrası depresyon için özelleşmiş tedaviler çok kısıtlıdır. Brexalonone tedavisi ile doğum sonrası depresyon tedavisinde özelleşmiş tedaviler güncel olarak gündeme gelmiştir. Bu derlememizde doğum sonrası depresyonun tanısı, etiyolojisi ve tedavisindeki yeni gelişmelerin önemini vurguladık. Bu veriler ışığında doğum sonrası depresyonun tanı, etiyoloji ve tedavisinde daha fazla klinik çalışmalara ihtiyaç olduğu söylenebilir.

\section{KAYNAKLAR}

1. Okanlı A, Tortumluoğlu G, Kırpınar İ. Gebe kadınların ailelerinden algıladıkları sosyal destek ile problem çözme becerileri arasındaki ilişki. Anadolu Psikiyatri Dergisi 2013; 4:98-105.

2. Hahn-Holbrook J, Cornwell-Hinrichs T, Anaya I. Economic and health predictors of national postpartum depression prevalence: a systematic review, meta-analysis, and meta-regression of 291 studies from 56 countries. Front Psychiatry 2017; 8:248.

3. Stewart DE, Robertson E, Dennis CL, Grace SL, Wallington T. Postpartum depression: Literature review of risk factors and interventions. University Health Network Women's Health Program for Toronto Public Health. 2003.

4. Lindahl V, Pearson JL, Colpe L. Prevalence of suicidality during pregnancy and the postpartum. Arch Womens Ment Health 2005; $8(2): 77-87$

5. American Psychiatric Association: Diagnostic and Statistical Manual of Mental Disorders (DSM-5), 5th ed. Arlington (VA): American Psychiatric Publishing; 2013.

6. Dünya Sağlık Örgütü. ICD-10 Ruhsal ve Davranıșsal Bozukluklar Sınıflandırılması. MO Öztürk, B Uluğ (Çeviri Ed), Ankara: Türkiye Sinir ve Ruh Sağlığı Derneği Yayını, 1993.

7. O'Hara MW, McCabe JE. Postpartum depression: current status and future directions. Annu Rev Clin Psychol 2013; 9:379-407.

8. Gavin NI, Gaynes, BN, Lohr KN, Meltzer-Brody S, Gartlehner G, Swinson, T. Perinatal depression: A systematic review of prevalence and incidence. Obstetrics and Gynecology 2005; 106:1071-1083.

9. Ayvaz S, Hocaoğlu Ç, Tiryaki A, Ak İ. Trabzon il merkezinde doğum sonrası depresyon sıklığı ve gebelikteki ilişkili demografik risk etmenleri. Türk Psikiyatri Dergisi 2006; 17(4):243-251.

10. Sunter AT, Guz H, Ordulu F. Samsun il merkezinde doğum sonrası depresyonu prevalansı ve risk faktorleri. VIII. Ulusal halk sağlığı kongresi kitabı 2002; 855-858.

11. Danacı AE, Dinç G, Deveci A, Sen FS, Içelli I. Postnatal depression in Turkey: Epidemiological and cultural aspects. Soc Psychatr
Epidemiol 2002; 37:125-129.

12. Aydin N, Inandi T, Karabulut N. Depression and associated factors among women within their first postnatal year in Erzurum province in eastern Turkey. Women Health 2005; 41:1-12.

13. Kroenke K, Spitzer RL, Williams JB. The PHQ-9: validity of a brief depression severity measure. J Gen Intern Med 2001; 16(9):606-613.

14. Wang SY, Jiang XY, Jan WC, Chen CH. Acomparative study of postnatal depression and its predictors in Taiwan and Mainland China. Am J Obstet Gynecol 2003; 189:1407-1412

15. Viinamaki H, Niskanen L, Pesonen P, Saarikoski S. Evolution of postpartum mental health. J Psychosom Obstet Gynecol 1997; 18:213-219.

16. Ișık MT, Akçınar M, Kadıoğlu S. Mersin ilinde gebelik, doğum ve loğusalık dönemlerinde anneye ve yenidoğana yönelik geleneksel uygulamalar. Uluslararası İnsan Bilimleri Dergisi 2010; 7(1):71-84.

17. Clark A, Skouteris H, Wertheim EH, Paxton SJ, Milgrom J. The relationship between depression and body dissatisfaction across pregnancy and the postpartum: A prospective study. J Health Psychol 2009; 14:27-35.

18. Brett M, Baxendale S. Motherhood and memory: a review. Psychoneuroendocrinology 2001; 26:339-362.

19. Frokjaer VG, Pinborg A, Holst KK, Overgaard A, Henningsson S, Heede M, Stenbæk D. Role of serotonin transporter changes in depressive responses to sex-steroid hormone manipulation: a positron emission tomography study. Biological psychiatry 2015; 78:534-543.

20. Pařízek A, Mikešová M, Jirák, R, Hill, M, Koucký M, Pašková A, Dušková M. Steroid hormones in the development of postpartum depression. Physiol Res 2014; 63 (Suppl 2):277-282.

21. Guintivano J, Arad M, Gould TD, Payne JL, Kmisnky ZA. Antenatal prediction of postpartum depression with blood DNA methylation biomarkers. Mol. Psychiatry 2014;19:560-567.

22. Roes M, Galea LA. The maternal brain: short-and long-term effects of reproductive experience on hippocampus structure and function in adulthood. Sex Differences in the Central Nervous System. Academic Press, 2016;197-220.

23. Bowen A, Muhajarine N. Antenatal depression. Canadian Nurse Journal 2006; 102:26-30.

24. Kalken G, Yılmazer M, Coşar E, Şahin FK, Cevrioğlu S, Geçiçi Ö. Nausea and vomiting in early pregnancy: Relationship with anxiety and depression. J Psychosom Obstet Gynaecol 2008; 29:91-95.

25. Brenda M, Leung Y, Bonnie ND, Kaplan J. Perinatal depression: prevelance, risks, and the nutrition link-a review of the literature. J Am Diet Assoc 2009; 109:1566-1577.

26. Bernstein IH, Rush AJ, Yonkers K, Carmody TJ, Woo A, McConnell K, et al. Symptom features of postpartum depression: are they distinct? Depress Anxiety 2008; 25(1):20-26. 
27. Dindo L, Elmore A, O'Hara M, Stuart S. The comorbidity of Axis I disorders in depressed pregnant women. Arch Womens Ment Health 2017; 20(6):757-764.

28. Erdem Ö, Bucaktepe PG. Postpartum depresyon görülme sıklığı ve tarama yöntemleri. Dicle Tıp Dergisi 2012;39 (3):446-458.

29. Morrell CJ, Slade P, Warner R, Paley G, Dixon S, Walters SJ, et al. Clinical effectiveness of health visitor training in psychologically informed approaches for depression in postnatal women: Pragmatic cluster randomised trial in primary care. British Medical Journal 2009; 338: 1-14.

30. Frieder A, Fersh M, Hainline M, Deligiannidis KM. Pharmacotherapy of Postpartum Depression: Current Approaches and Novel Drug Development. CNS Drugs 2019; 33:265-282.

31. Stowe ZN, Casarella J, Landry J, Nemeroff CB. Sertraline in the treatment of women with postpartum major depression. Depression 1995; 3(1-2):49-55.

32. Wisner KL, Hanusa BH, Perel JM, Peindl KS, Piontek CM, Sit DK, et al. Postpartum depression: a randomized trial of sertraline versus nortriptyline. J Clin Psychopharmacol. 2006; 26(4):353-360.

33. Dennis CL, Ross LE, Herxheimer A. Oestrogens and progestins for preventing and treating postpartum depression. Cochrane Database Syst Rev. 2008; 4.

34. Ward HB, Fromson JA, Cooper JJ, De Oliveira G, Almeida M. Recommendations for the use of ECT in pregnancy: literature review and proposed clinical protocol. Arch Womens Ment Health 2018; 21(6):715-722.

35. US FDA. FDA approves first treatment for post-partum depression. 2019. http://www.fda.gov/. Accessed 22 Mar 2019.

36. Marcus SM. Depression during pregnancy: rates, risks and consequences. Journal of Population Therapeutics and Clinical Pharmacology 2009; 16(1).

37. Misri SR, Reebye P, Corral M, Mills L. The use of paroxetine and cognitivebehavioral therapy in postpartum depression and anxiety: A randomized controlled trial. Journal of Clinical Psychiatry 2004; 65:1236-1241.

38. De Crescenzo, F, Perelli F, Armando M, Vicari S. Selective serotonin reuptake inhibitors (SSRIs) for post-partum depression (PPD): a systematic review of randomized clinical trials. Journal of Affective Disorders 2014; 152:39-44.

39. Suri R, Burt VK, Altshuler LL. Nefazodone for the treatment of postpartum depression. Arch Womens Ment Health. 2005;8(1):5556.

40. Gregoire AJ, Kumar R, Everitt B, Henderson AF, Studd JW. Transdermal oestrogen for treatment of severe postnatal depression. Lancet. 1996; 347(9006):930-933.

41. Vigod S, Dennis CL, Daskalakis Z, Murphy K, Ray J, Oberlander T, et al. Transcranial direct current stimulation (tDCS) for treatment of major depression during pregnancy: study protocol for a pilot randomized controlled trial. Trials 2014; 15:366.

42. Deligiannidis KM, Sikoglu EM, Shaffer SA, Frederick B, Svenson AE, Kopoyan A, Moore CM. GABAergic neuroactive steroids and resting-state functional connectivity in postpartum depression: a preliminary study. Journal of psychiatric research 2013; 47(6):816828.

43. Melón LC, Hooper A, Yang X, Moss SJ, Maguire J. Inability to suppress the stress-induced activation of the HPA axis during the peripartum period engenders deficits in postpartum behaviors in mice. Psychoneuroendocrinology 2017; 90:182-193.

44. Kanes S, Colquhoun H, Gunduz-Bruce H, et al. Brexanolone (SAGE547 injection) in post-partum depression: a randomised controlled trial. Lancet 2017; 390: 480-489.

45.Zorumski CF, Paul SM, Izumi Y, et al. Neurosteroids, stress and depression: potential therapeutic targets. Neurosci Biobehav Rev 2013; 37(1):109-122.

46. Hoffmann E, Wald J, Colquhoun H. Evaluation of breast milk concentrations following brexanolone iv administration to healthy lactating women. Am J Obstet Gynecol 2019; 220( suppl 1):554.

47. Meltzer-Brody S, Colquhoun H, Riesenberg R, et al. Brexanolone injection in post-partum depression: two multicentre, double blind, randomised, placebo-controlled, phase 3 trials. Lancet 2018; 392(10152):1058-1070.

48. Kanes SJ, Colquhoun IH, Doherty J, Raines S, Hoffmann E, Rubinow DR, Meltzer-Brody S. Open-label proof-ofconcept study of brexanolone in the treatment of severe postpartum depression. Hum Psychopharmacol 2017; 32(2):2576. 